\title{
Cultivation of Learners' Autonomy through Strategy Training Xiao-Fang WANG
}

School of Foreign Languages, Nanyang Institute of Technology, Nanyang, Henan Province, China xfwdfy@126.com

Key words: learning strategies; learning strategy training; learners' autonomy

\begin{abstract}
English teaching, teaching mode focusing on learnerscenteredness and highlighting learner autonomy has become a hot in foreign language teaching. Cultivation of learner autonomy is considered as one of the most important goals in language teaching. Based on the critical role strategies play in fostering learners' autonomy, the present paper offers a strategies-based instruction (SBI), that is, explicitly embedding learning strategies into normal teaching through strategy training to promote learners' autonomy. The findings show that strategy training can improve learners' strategy awareness and use frequency effectively. With strategies integrated into learning tasks, learners' autonomous learning ability can be greatly enhanced.
\end{abstract}

\section{Introduction}

Among learners' individual factors affecting their independent learning, learning strategies play a vital part for the reorganization and reconstruction of knowledge. That means whether learners can use learning strategies flexibly and successfully will directly influence their overall learner autonomy. So the paper here is hoped to cultivate learners' autonomy through learning strategy instruction by explicit training in teaching.

\section{Learner Autonomy and Learning Strategies}

According to Gardner \& Miller (1999: 6-7), there are two influential definitions put forward respectively by Holec and Dickinson: Holec (1981:3) has defined autonomy as "the ability to take charge of one's own learning". Dickinson (1987: 11) has identified the definition of autonomy as a "situation in which the learner is totally responsible for all of the decisions concerned with his or her learning and the implementation of those decisions".

The concept of "learning strategies" is partly based on cognitive learning theory, in which learning is viewed as an active, mental, learner-constructed process. The goal of strategy use is to "affect the learner's motivational or affective state, or the way in which the learner selects, acquires, organizes, or integrates new knowledge" (Weinstein and Mayer 1986:135).

In the 1990s, researchers combined the study of language learning strategies with that of learner autonomy, for the ultimate goal of teaching is to help students become independent, autonomous and effective learners. So fostering students' strategies is not only to promote their learning scores in school, but also to improve their autonomous learning abilities for lifelong learning.

Learning strategies can make great contributions to learner autonomy and language achievements in learning a second language. By transferring more responsibility to learners for their own language development, language tasks can help learners to become more self-directed, to diagnose strengths and weaknesses in learning, and to self-regulate language learning process. To put it in another way, learners are being encouraged to use different kinds of strategies to manage their own learning. Strategies are not only components of learner autonomy but also tools that help learners become more autonomous.

\section{Learning Strategy Training}

Learning strategies play a critical role in the promotion of learner autonomy. Learning will be promoted if learners are explicitly trained to be clear about and more efficient in using a mixture of 
strategies during the whole learning process. Experienced learners can solve language-learning problems in a systematic way and are usually skilled in selecting appropriate strategies to complete a language-learning task (O'Malley \& Chamot 1995:146). Cohen (2000:67) also claims that: "Strategy training can help to exert learners' efforts to achieve learning goals in that it inspires students to seek their own shortcuts to success, and thus it enhances learner autonomy and self-regulated learning." Cohen holds the idea that a further purpose of strategy training is to cultivate autonomous learning by giving learners more freedom to select and use strategies that are most suitable for themselves, without much prompt from language teachers.

\section{Goals of Strategy Training}

Strategy training is applied to explicitly teaching learners how to use strategies, which can enhance learners' efforts to reach language goals (Oxford and Leaver 1996).

Three major goals for strategy training are identified:

(1) To explicitly instruct learners why, when, and how learning strategies can be used to promote their foreign language learning;

(2) To help learners explore methods that they can take to learn the target language more effectively, and at the same time to encourage learners to self-regulate their learning;

(3) To cultivate learner autonomy by offering learners opportunities to select appropriate strategies without constant prompt from their teachers.

\section{Strategy Training Approaches}

Previous researches have presented many favorable strategy training approaches in a variety of educational settings. Approaches available are as follows: general training on study techniques that is separated from the language course content; awareness training both through lectures and workshops to get learners familiar with strategy applications; peer tutoring to carry mutual tutoring sessions for students with different backgrounds; videotaped mini-courses to help students get to know the concept of learning strategies and the learning process and take charge of their learning; the direct insertion of strategies into textbooks to reinforce strategy use through both learning tasks and skills, and strategies-based instruction in which strategy training is systematically imbedded into the language course teaching under teachers' guidance.

Strategies-based instruction (SBI) is a learner-focused method by which learning strategies are explicitly and implicitly inserted into the course content. Teachers who adopt strategies-based instruction can make the strategy training individualized in terms of teaching requirements. Meanwhile, teachers can present and reinforce specific strategies during the regular course presentation. (Cohen, 1998)

\section{CALLA for Strategy Training}

CALLA approach is a five-step model: introduction, presentation, practice, evaluation, and expansion. This approach gets access to highly explicit instruction through applying strategies to specific learning tasks and helps learners take more responsibility for selecting and applying and transferring appropriate learning strategies.

The goal and focus of CALLA is to afford learners the opportunity to learn a new language independently and to become self-regulated as learners by consistently dominating the various strategies of learning in a classroom setting.

\section{Training Design}

This paper holds the belief that language learning will be promoted through explicit strategy training to enhance learners' awareness of strategies. The most efficient way to heighten learner awareness is to provide strategy training-explicit instruction in how to apply language learning strategies.

SBI is an approach to teaching featuring learner-centeredness. Learners are allowed to experience systematic application of strategies to learning and using the target language. And opportunities are 
available for them to share their favorable strategies with classmates to double their strategies use during language task performances.

A CALLA (Cognitive Academic Language Learning Approach) lesson is built around the following five steps:

(1) Preparation-learners' background knowledge and schemata about the content being studied as well as their learning strategies are explored.

(2) Presentation — the teacher presents the necessary new content and learning skills needed for the lesson.

(3) Practice-learners perform various activities to reinforce the material to be learned.

(4) Evaluation-learners evaluate their own learning.

(5) Expansion-learners use what they have learned and apply it to new situations.

\section{Training Sample}

Strategy training for reading comprehension adopts the model of CALLA developed by O'Malley and Chamot through strategies-based instruction (SBI).

Approach: Strategies-based instruction

Training model: Cognitive Academic Language Learning Approach (CALLA)

Materials: Reading materials from the textbook New College English Integrated Course 1

Reading Strategies to be trained: Inferencing for word recognition

Training Process:

Stage 1 Preparation: Raising learners' awareness of reading strategies

Stage 2 Presentation: Explaining and Modeling (selected example)

Stage 3 Practice (contents from the text)

Stage 4 Evaluation (pair work or group work)

Stage 5 Expansion (relevant exercises to consolidate)

Unit 1 Growing Up

Table 1 Text A Writing for Myself

\begin{tabular}{|l|l|}
\hline \multicolumn{2}{|l|}{ Inferencing for word recognition } \\
\hline Language objective & Reading to have a better understanding of vocabulary and the text. \\
\hline Strategy objective & Making educated guesses at the meanings of new words. \\
\hline
\end{tabular}

Stage 1 Preparation: Raising learners' awareness of reading strategies

In this part, the teacher informs the learners that she will be introducing strategies to improve their reading. Then, the teacher shows a text to the learners and asks them to identify new words and guess at the meaning of each new word.

For drivers, the monotonous process of staring at the center divider for long hours is a life-threatening hazard.

The learners will be asked to give reasons for their guesses and ways to apply to dealing with new words in reading. At last, the teacher tells the class that when they are guessing, they are using a reading strategy named "inferencing" and in this text, this strategy will be introduced and other reading strategies followed.

Stage 2 Presentation: Explaining and Modeling (selected example)

The definition of "inferencing" is given, i.e., to make clever guesses at the meaning of words, sentences, or any unfamiliar part in the text using whatever knowledge sources available-various types of world knowledge, contextual and linguistic knowledge.

Here comes to the crucial step for the teacher to model the use of strategies.

Selected example:

For drivers, the monotonous process of staring at the center divider for long hours is a life-threatening hazard. 
Table 2 the Process of Explaining and Modeling the Strategy

\begin{tabular}{|l|l|}
\hline Teacher's think-aloud processes & Strategies \\
\hline I don't know the word "monotonous". & $\begin{array}{l}\text { Here I'm picking out a problem } \\
\text { word-problem identification. }\end{array}$ \\
\hline $\begin{array}{l}\text { The structure of the word is "mono" and "tonous". } \\
\text { "mono" is a prefix which means "single". So "The } \\
\text { monotonous process" may means "The single } \\
\text { process". }\end{array}$ & $\begin{array}{l}\text { Here I'm using my knowledge about } \\
\text { English language (prefix) to guess } \\
\text { the unknown word. }\end{array}$ \\
\hline I don't know the word "hazard". & $\begin{array}{l}\text { Here I'm picking out a problem } \\
\text { word-problem identification. }\end{array}$ \\
\hline $\begin{array}{l}\text { According to the phrase "a life-threatening hazard", } \\
\text { I get to know the word "hazard" is a noun. }\end{array}$ & $\begin{array}{l}\text { Here I'm using my grammatical } \\
\text { knowledge (a ... } \\
\text { grammatical function. guess its }\end{array}$ \\
\hline $\begin{array}{l}\text { Looking at the whole sentence, I notice that there are } \\
\text { some words which can help me identify the meaning } \\
\text { of "hazard". They are "drivers", "process", "staring } \\
\text { at", "for long hours", and "life-threatening". }\end{array}$ & $\begin{array}{l}\text { Here I'm using the contextual clues } \\
\text { to help me guess the meaning. }\end{array}$ \\
\hline $\begin{array}{l}\text { When we stare at something for long hours, it is } \\
\text { dangerous for our eyes or potential danger would } \\
\text { arise. So the word must mean "dangerous" or } \\
\text { "something dangerous". }\end{array}$ & $\begin{array}{l}\text { I'm confirming my previous guess } \\
\text { with my general knowledge of the } \\
\text { world. }\end{array}$ \\
\hline $\begin{array}{l}\text { When I look at the whole sentence again, I have } \\
\text { already known the meaning of it. "For drivers, it is } \\
\text { quite dangerous or life-threatening to stare at the } \\
\text { center divider for long hours." }\end{array}$ & $\begin{array}{l}\text { I'm evaluating both } \\
\text { understanding of the text and the } \\
\text { successfulness of my guessing. }\end{array}$ \\
\hline
\end{tabular}

Stage 3 Practice (contents from the text)

This step is to present the second paragraph of the text "Writing for Myself" on the screen and the learners are asked to guess the word "severe".

When our class was assigned to Mr. Fleagle for third-year English I anticipated another cheerless year in that most tedious of subjects. Mr. Fleagle had a reputation among students for dullness and inability to inspire. He was said to be very formal, rigid and hopelessly out of date. To me he looked to be sixty or seventy and excessively prim. He wore primly severe eyeglasses, his wavy hair was primly cut and primly combed. He wore prim suits with neckties set primly against the collar buttons of his white shirts. He had a primly pointed jaw, a primly straight nose, and a prim manner of speaking that was so correct, so gentlemanly, that he seemed a comic antique. (Russell Baker, 1982)

Teacher's explanation: I don't know the word "severe". Let's have a look at the words or sentences around it. The sentences "He was said to be very formal, rigid and hopelessly out of date." and "To me he looked to be sixty or seventy and excessively prim." tell us the man is formal, out of date, and elderly, which indicates that he is not a casual and fashionable person. According to the position of the word "severe" in the sentence, we can know part of speech of the word, an adjective. Thus, if he wears a pair of glasses, we will know the its style: formal, unfashionable, plain which may be the meaning of the word "severe".

Next, the teacher asks the learners to accomplish the rest of the text in this way and take notes of strategies used during the following reading. Then the teacher pairs up the students and asks each pair to share how they made their guesses.

Stage 4 Evaluation (pair work or group work)

The teacher asks each pair to do the following step by step.

List all clues they have employed to guess unknown words.

Check whether the use of the guessing strategy helping their reading comprehension.

Think if they can now use the same guessing strategy on their own. 
The teacher gives positive feedback to encourage the learners' efforts.

Stage 5 Expansion (relevant exercises to consolidate)

The teacher suggests that the learners use the inferencing strategy in their reading of the textbook, and that they incorporate the strategy into their regular homework readings.

\section{Findings}

After strategy training, learners' strategy use has been greatly improved and the merits are mainly included as follows:

(1) The learners' awareness of learning strategy use has been greatly raised. Through the teacher's instruction, the learners' sense of strategies has been gradually strengthened, which is rather important for the training, as they should gain the awareness first, and thus strategies can be used flexibly to better their language performance. (2) The learners began to select and use a set of strategies they need for specific learning tasks consciously. They acquired the classification of learning strategies and put them into practical use which helped accelerate their language learning. The learners who received learning strategy training outperformed those who did not learn the strategies systematically. (3) The learners gradually realized they should be responsible for their learning. After the training, the learners' attitude toward learning has changed. Most learners began to know what learner autonomy is and how to undertake autonomous learning. (4) The learners could identify and develop learning strategies to achieve target goals and became autonomous learners. The learners have increased a lot in selecting and using strategies. To sum up, the training helped the learners implement more use of different strategies and enabled them to become more autonomous in language learning process.

\section{Conclusion}

As this paper mainly concerns with learners' strategy use in class to develop autonomy, further research can be focused on learners' out-of-class language learning or computer-assisted learning so that whether their classroom learning fits into other situations can be examined. This also constitutes a challenge to the teachers to develop their expertise to better assist students working towards autonomy both in class and out of class. It is hoped that more teachers will be stimulated to explore new areas of research and methodologies that will contribute to our knowledge of autonomy both in theory and practice.

\section{Acknowledgement}

This paper was financially supported by the Project, Research on Science and Engineering Majors-Oriented College English Teaching Reform (NIT2014TSJG-03).

\section{References}

[1] Chamot, A. U. \& O’Malley, J. M. The CALLA Handbook: Implementing the Cognitive Academic Language Learning Approach. MA: Addison-Wesley, 1994.

[2] Cohen, A.D. Strategies in Learning and Using a Second Language. London: Longman, 1998.

[3] Cohen, A. D. Strategies in Learning and Using a Second Language. Beijing: Foreign Language Teaching and Research Press, 2000

[4] Dickinson, L. Self-Instruction in Language Learning. Cambridge: Cambridge University Press, 1987.

[5] Gardner, D. \& Miller, L. Establishing Self-Access: From Theory to Practice. Cambridge: Cambridge University Press, 1999.

[6] Gardner, D. \&Miller, L. Establishing Self-Access-From Theory to Practice. Shanghai: 
Shanghai Foreign Language Education Press, 2002.

[7] Holec, H. Autonomy and Foreign Language Learning. Oxford: Pergamon Press, 1981.

[8] O’Malley and Chamot. Learning Strategies in Second Language Acquisition. UK: Cambridge University Press, 1995.

[9] O’Malley and Chamot. Learning Strategies in Second Language Acquisition. Shanghai: Shanghai Foreign Language Education Press, 2001.

[10] Oxford, R. L. Language Learning Strategies: What Every Teacher Should Know. Boston: Heinle Publishers, 1990.

[11] Oxford, R. L. \& Leaver, B. L. A Synthesis of Strategy Instruction for Language Learners. Ed. Oxford, R. L. Language Learning Strategies Around the World: Cross-cultural Perspectives. Second Language Teaching \& Curriculum Center, University of Hawaii. Honolulu: (1996): 46-227.

[12] Weinstein, C. E., and R E. Mayer. The Teaching of Leaning Strategies. Ed. M. C. Wittrock. New York: Macmillan, 1986.

[13] Yong-Qi GU, Guang-Wei HU, Jun ZHANG and Rui BAI. Strategy-Based Instruction: Focusing on Reading and Writing Strategies. Beiing: Foreign Language Teaching And Research Press,2011. 